Opinie

\title{
Cum măsurăm creativitatea muzicală? O perspectivă asupra creditelor creative. ${ }^{1}$
}

\section{Dan DEDIU ${ }^{1 *}$}

1 Universitatea Națională de Muzică București,
dan.dediu@unmb.ro
* Correspondent: gabi.lupu@ub.ro
Citation: Dediu, D. (2021). Cum măsurăm creativitatea muzicală? 0 perspectivă asupra creditelor creative. Etică și Deontologie. 1(2), 50-55

https://doi.org/10.52744/RED.2021.02.06

Publisher's Note: RED stays neutral with regard to jurisdictional claims in published maps and institutional affiliations.

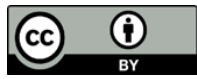

Copyright: (C) 2021 by the authors. Submitted for possible open access publication under the terms and conditions of the Creative Commons Attribution (CC BY) license (https://creativecommons.org/ licenses/by/4.0/).
Rezumat: Fluctuațiile creativității muzicale sunt nenumărate, iar cazuistica de gen depășește orice imaginație. Pentru a putea cuprinde cât de cât această multitudine de manifestări, am imaginat un sistem ce definește diferite fenomene muzicale existente și le "cântărește" gradul de creativitate conținut în materialul sonor propus spre audiție sau studiu. Este un sistem analog cu cel al creditelor transferabile din educație. Această analogie s-a născut urmare a reflecției asupra multiplelor aspecte ale compoziției muzicale și din încercarea de a găsi (regăsi) o ordine în haosul de acțiuni și lucrări ce o populează. Am numit acest sistem - creditele creative.

Cuvinte cheie: creativitate muzicală, credite creative, credite transferabile, etică

Abstract: The fluctuations of musical creativity are innumerable, and gender casuistry goes beyond any imagination. In order to be able to comprehend this multitude of manifestations, we imagined a system that defines different existing musical phenomena and "weighs" the degree of creativity contained in the sound material proposed for audition or study. It is a system analogous to that of transferable credits from education. This analogy was born from the reflection on the multiple aspects of the musical composition and from the attempt to find (rediscover) an order in the chaos of actions and works that populate it. I called this system - creative loans.

Key words: musical creativity, creative credits, transferable credits, ethics

\footnotetext{
${ }^{1}$ Articol prezentat în cadrul Conferinței Internaționale Valorile Etice în Societatea Actuală - VESA 2021 (3-5 iunie).
} 


\section{Introducere}

Fluctuațiile creativității muzicale sunt nenumărate, iar cazuistica de gen depășește orice imaginație. Pentru a putea cuprinde cât de cât această multitudine de manifestări, am imaginat un sistem ce definește diferite fenomene muzicale existente și le „cântărește” gradul de creativitate conținut în materialul sonor propus spre audiţie sau studiu. Am numit acest sistem - creditele creative.

Ce este sistemul creditelor creative? Este un sistem analog cu cel al creditelor transferabile din educație. Această analogie mi-a venit în minte atunci când reflectam asupra multiplelor aspecte ale compoziției muzicale și încercam să găsesc o ordine în haosul de acțiuni și lucrări ce o populează. Mi se pare că această analogie este interesantă și vă voi înfățișa pe scurt ideile de pornire, apoi o taxonomie succintă, care poate fi cuprinsă schematic pe o scală de la $100 \%$ la $0 \%$.

Dacă este să vorbim de credite, aceasta este o noțiune financiară, importată la rândul ei în domeniul educației europene ca ECTS (European Credit Transfer System) pentru a permite compararea sistemelor de învățământ superior din Europa. Conceptele centrale sunt „learning outcomes”, adică „rezultatele învățării”, competențele (ce trebuie să cunoască, să înțeleagă și să fie capabili să facă studenții) și „workload”, ceea ce s-ar putea înțelege ca volumul de muncă implicat în procesul învățării (cantitatea de timp aproximativă de care au nevoie studenții pentru a ajunge la aceste rezultate).

În consecință, se poate imagina un sistem al creditelor creative, adică al aportului original în creație și al gradelor de derivație de la original. Pe scurt, un sistem care să măsoare volumul de creativitate.

În acest sens, propun trei criterii de măsurare, deocamdată:

1. conținutul muzical, adică organizarea înălțimilor/duratelor, ce poate fi original/derivat/corupt/copie;

2. articularea temporală, cuprinzând ideea formală/forma muzicală, ce poate fi inedită/preformată/fixă;

3. anvelopa sonoră, pendulând între timbralitate nouă sau timbralitate cunoscută, scriitură similară sau scriitură diferită.

Pornind de aici, printr-un demers combinatoric simplu se pot imagina grade de aport creativ (Creative-Volume-Load, prescurtat CVL) sub raportul materialului muzical:

1. Original ex nihilo. În acest caz, totul este la 100\%: conținutul muzical, forma, noutatea timbrală. 
2. Original derivat dintr-o operă existentă. Aici suntem în prezența unei muzici compuse pornind de la un pre-text sau de la un text muzical existent, care amorsează posibilități diverse de dezvoltare. Este echivalentul comentariului de text filosofic, care poate porni în apropierea sensului și poate apoi crea paranteze, extrapola, inventa alte concepte.

a. variațiuni pe o temă preluată (temă preluată și variațiuni originale): conținutul muzical este preformat inițial, anume tema; de-abia după aceea, prin învârtirea în jurul acestui nucleu se generează un conținut nou; forma muzicală poate fi mai apropiată sau mai depărtată de tema preluată (în variațiunile stricte aceasta se păstrează, în variațiunile libere ea poate varia sau se poate schimba complet); timbralitatea sau scriitura se poate păstra, dar poate și diferi.

b. citat (inserții preluate simbolic și transformate creativ): două sau mai multe tipuri de conținut eterogen: folosirea citatului este grefarea unei copii întrun text original, în ideea de a clarifica, lămuri ori potența sensul existent, ori în ideea de a crea un punct de fugă care să deschidă spre alte orizonturi semantice. În citat, conținutul muzical are $0 \%$ aport creativ, $100 \%$ aport al articulării temporale, $50 \%$ timbralitate, căci poate apărea la alte instrumente, ca într-un aranjament (un exemplu de citat inserat ca aranjament Coralul "Es ist genug" din Concertul pentru vioară de Alban Berg).

3. Original după model-schematic/stilistic. Avem de-a face aici cu o muzică originală, dar derivată dintr-o schemă stilistică pre-existentă, ca o matriță în care e pus material divers. Conținut asemănător, formă identică, timbralitate diferită. Este aproape de copie, dar nu se confundă cu ea.

a. Parodie: o imitație cu sens schimbat, o copie care spune contrariul originalului, realizată cu umor sau sarcasm, ingrediente obligatorii pentru parodie. Conținutul e corupt, forma identică, timbralitatea diferită.

b. Pastișă și/sau parafrază (à la manière de): imitație apropiată de original, în aceeași "clasă de compoziții". Pastișa/parafraza poate fi realizată cu intenție, ca omagiu, ca mască asumată programatic (a se vedea piesele Paganini și Chopin din "Carnavalul" op. 9 de Robert Schumann) sau poate fi realizată fără intenție, epigonic și cu aport minim de creativitate.

4. Copie parțială. Aici ne aflăm în imperiul lui readymade, a muzicii gata făcute. Astfel, nu mai putem vorbi decât de o creativitate condusă în limitele unei opere de artă deja existente, prin apelul la câteva artificii de schimbare neesențială a originalului existent. Avem în acest caz două opțiuni: 
să păstrăm integritatea ontologică a operei de artă și doar să o „coafăm”, să o „costumăm” diferit prin folosirea unor alte instrumente sau voci sau să rupem integritatea ontologică a operei de artă, decupând din ea fragmente și punându-le în alte contexte și forme, dar păstrându-i înfățișarea timbrală (prin folosirea înregistrărilor).

a. Anvelopă timbrală diferită, integritate ontologică a operei

i. Aranjament: adaptarea și extinderea creatoare, cu adaosuri, a unui text muzical de la un instrument/voce/ansamblu la un alt instrument/ voce/ansamblu.

ii. Transcripție: preluarea identică sau cu minime adaptări a unui text muzical de la un instrument/voce/ansamblu la alt instrument/voce/ ansamblu. Mai poate fi dată o definiție, ceva mai simplă: trecerea unei muzici dintr-un mediu timbral într-un alt mediu timbral (vocal $\rightarrow$ instrumental, instrumental $\rightarrow$ vocal, vocal $\rightarrow$ vocal, instrumental $\rightarrow$ instrumental)

iii. Orchestrație: expandarea unei muzici instrumentale la un ansamblu orchestral

iv. Reducție: esențializarea unei muzici orchestrale la strictul necesar și reducerea ei la un singur instrument, de regulă pianul.

b. Anvelopă timbrală identică (sample), ruptură a integrității ontologice (selection)

i. Instalație originală. Folosirea eșantioanelor într-un mod original, astfel încât anvelopa sonoră să fie originală. Lucrul cu readymade ca sample, dar configurație sintactică originală.

ii. Montaj. Folosirea eșantioanelor dintr-o singură sursă sau stil, combinate (succesiv și simultan) după o logică anume sau fără nicio logică (montaj omogen). Folosirea eșantioanelor din mai multe surse sau stiluri, combinate (succesiv și simultan) după o logică anume sau fără nicio logică (montaj eterogen sau colaj).

iii. Mixaj. Suprapunerea mai multor piste (ce conțin teoretic mai multe instrumente sau eșantioane sau stiluri) și mixarea lor, ierarhizarea lor după volum și pregnanță, sculptare în intensitate și spațialitate. Este domeniul DJ-ului, după cum ușor se poate observa.

5. Copie identică - plagiat. Aici orice comentariu e de prisos, căci aportul creator este 0 . 
Desigur, rămâne problema ilustrației muzicale. Ea face parte din alt continent, anume cel al suportului muzical anexat unei alte arte principale. În ilustrația muzicală, muzica este pe locul doi, accentul picând în principal pe arta aflată în prim plan: literatură, pictură, film, dans. În ilustrația muzicală aportul de creativitate este de altă natură, efortul fiind îndreptat spre adecvarea și asortarea la/cu alt material artistic. E mai mult un act de cultură, decât unul de creație: e ca și cum am vorbi în citate și am dori să avem drepturi de autor pentru conținut.

Iată mai jos o sistematizare schematică a întregului traseu pe care l-am străbătut, dublată și de o propunere de acordare a unui număr de credite creative fiecărei specii evidențiate anterior. La ce ar putea folosi așa ceva? La o măsurare relativ onestă a gradelor de creativitate implicate în procesul compoziției muzicale. Desigur, cu toții creăm mânați de la spate de anxietatea influenței, după cum spunea Harold Bloom. Dar unii sunt mai mult, alții mai puțin influențaţi de modelele precedente. Iar cantitatea de creativitate implicată într-un opus muzial e clar că depinde de mai mulți factori. Și totuși, cantitatea de creativitate există. Se vede cu ochiul liber dacă comparăm o operă de Verdi cu aranjamentul unei arii dintr-o operă de Verdi sau cu începutul unei melodii de Verdi preluată ca readymade identic și transformată într-o reclamă de succes la berea Stella Artois.

\section{Muzică în sine}

\begin{tabular}{|c|c|c|c|c|}
\hline 1. & \multicolumn{4}{|l|}{ Original ex nihilo } \\
\hline \multirow[t]{2}{*}{2.} & \multirow{2}{*}{$\begin{array}{l}\text { Original derivat } \\
\text { dintr-o operă } \\
\text { existentă }\end{array}$} & \multicolumn{3}{|c|}{$\begin{array}{l}\text { variațiuni pe o temă preluată (temă preluată și variațiuni } \\
\text { originale) }\end{array}$} \\
\hline & & \multicolumn{3}{|c|}{ citat (inserții preluate simbolic și transformate creativ) } \\
\hline \multirow[t]{2}{*}{3.} & \multirow{2}{*}{$\begin{array}{l}\text { Original după } \\
\text { model } \\
\text { schematic/stilistic }\end{array}$} & \multicolumn{3}{|l|}{ parodie } \\
\hline & & \multicolumn{3}{|c|}{ pastișă/parafrază (à la manière de) } \\
\hline \multirow[t]{8}{*}{4.} & \multirow{8}{*}{$\begin{array}{l}\text { Copie parțială } \\
\text { Imperiul lui } \\
\text { readymade }\end{array}$} & \multirow{4}{*}{$\begin{array}{l}\text { anvelopă timbrală diferită, } \\
\text { integritate ontologică a operei }\end{array}$} & \multicolumn{2}{|c|}{ Aranjament } \\
\hline & & & \multicolumn{2}{|c|}{ Transcriptie } \\
\hline & & & \multicolumn{2}{|c|}{ Orchestrație } \\
\hline & & & \multicolumn{2}{|c|}{ Reducție } \\
\hline & & \multirow{4}{*}{$\begin{array}{l}\text { anvelopă timbrală identică } \\
\text { (sample), ruptură a integrității } \\
\text { ontologice (selection) }\end{array}$} & \multicolumn{2}{|c|}{ Instalație originală } \\
\hline & & & \multirow[t]{2}{*}{ Montaj } & omogen \\
\hline & & & & $\begin{array}{l}\text { neomogen } \\
\text { (colaj) }\end{array}$ \\
\hline & & & \multicolumn{2}{|l|}{ Mixaj } \\
\hline 5. & \multicolumn{4}{|c|}{ Copie identică - plagiat } \\
\hline
\end{tabular}

(C) Dan Dediu, 2016 
Propunere de acordare a creditelor creative

\begin{tabular}{|c|c|c|c|c|c|}
\hline \multirow{3}{*}{$\frac{1 .}{2}$} & \multicolumn{4}{|l|}{ Original ex nihilo } & 100 \\
\hline & \multirow[t]{2}{*}{$\begin{array}{l}\text { Original derivat } \\
\text { dintr-o operă existentă }\end{array}$} & \multicolumn{3}{|c|}{$\begin{array}{l}\text { variațiuni pe o temă preluată (temă preluată și variațiuni } \\
\text { originale) }\end{array}$} & 80 \\
\hline & & \multicolumn{3}{|c|}{ citat (inserții preluate simbolic și transformate creativ) } & 80 \\
\hline \multirow[t]{2}{*}{3.} & \multirow{2}{*}{$\begin{array}{l}\text { Original după model } \\
\text { schematic/stilistic }\end{array}$} & \multicolumn{3}{|l|}{ parodie } & 60 \\
\hline & & \multicolumn{3}{|l|}{ pastișă/ parafrază (à la manière de) } & 40 \\
\hline \multirow[t]{8}{*}{4.} & \multirow{8}{*}{$\begin{array}{l}\text { Copie parțială } \\
\text { Imperiul lui readymade }\end{array}$} & \multirow{4}{*}{$\begin{array}{l}\text { anvelopă timbrală diferită, integritate } \\
\text { ontologică a operei }\end{array}$} & \multirow{2}{*}{\multicolumn{2}{|c|}{$\begin{array}{l}\text { Aranjament } \\
\text { Transcriptie }\end{array}$}} & 20 \\
\hline & & & & & 15 \\
\hline & & & \multicolumn{2}{|c|}{ Orchestrație } & 20 \\
\hline & & & \multicolumn{2}{|c|}{ Reductie } & 15 \\
\hline & & \multirow{4}{*}{$\begin{array}{l}\text { anvelopă timbrală identică (sample), } \\
\text { ruptură a integrității ontologice } \\
\text { (selection) }\end{array}$} & \multicolumn{2}{|c|}{ Instalație originală } & 10 \\
\hline & & & \multirow[t]{2}{*}{ Montaj } & omogen & 8 \\
\hline & & & & $\begin{array}{l}\text { neomogen } \\
\text { (colaj) }\end{array}$ & 5 \\
\hline & & & \multicolumn{2}{|l|}{ Mixaj } & 3 \\
\hline 5. & \multicolumn{4}{|l|}{ Copie identică - plagiat } & 0 \\
\hline
\end{tabular}

() Dan Dediu, 2016 